\section{Testicular feminisation syndrome: unusual gonadal histology in an elderly patient}

SUMMARY The gonads of an elderly patient with a typical testicular feminisation syndrome are described. The unusual histological features consisted of total absence of testicular tubular structures or remnants thereof and distinct proliferation of smooth muscle bundles. In addition, there was fibrous proliferation, areas of ovarian stroma, and rare Reinke crystalloids within Leydig cells. The complete tubular absence may have been the result of fibrous replacement related to the patient's advanced age, while the muscular proliferation may have been of hamartomatous nature. Thus, it seems that in elderly patients with testicular feminisation syndrome, the histological appearance of the gonads may vary considerably from that in younger individuals, and in such cases the correct diagnosis should be based mainly on clinical and cytogenetic findings.

The gonads of patients with testicular feminisation syndrome resemble cryptorchid testes with varying degrees of atrophy, absence of or conspicuously decreased spermatogenesis, and hyperplasia of interstitial cells (Morris and Scully, 1958; Stenchever et al. 1959). Tubular structures are a definite component of such gonads. As in undescended testes, tubular adenomas have also been frequently observed (Morris and Scully, 1958; O'Connell et al., 1973). These patients are genetic males, with normal female external genitalia, a blindly ending vagina, and absent uterus (Federman, 1967; Morris, 1953; Stenchever et al., 1969).

The case reported here is that of an elderly patient with an otherwise typical testicular feminisation syndrome, but with a most unusual histological appearance of the gonads. Possible mechanisms leading to such gonads in this syndrome will be discussed.

\section{Case report}

A 65-year-old married woman of Jewish-Turkish extraction was admitted to the hospital because of upper abdominal pains and vomiting, caused by peptic ulcers in the pyloric channel and duodenum. She had been married for over 30 years, had never menstruated, and was childless. She was the only daughter of first-degree cousins, and had several normal brothers. Her mother had two normal sisters and one brother, married and with children; two additional sisters had primary amenorrhoea and were phenotypically similar to the patient.

Physical examination revealed an obese phenotypic female, with complete lack of axillary and pubic hair. The breasts were well developed and large, the areolae were non-pigmented and the nipples appeared pubertal. The external genitalia were female. A narrow short vagina was found, ending in a blind pouch. The clitoris was not enlarged, and no uterus was palpated.

Pertinent laboratory tests: 17-ketosteroids $2 \cdot 37$ $\mathrm{mg} / 24 \mathrm{hr}(8 \cdot 22 \mu \mathrm{mol} / 24 \mathrm{hr}$ ) (normal: $1-7 \mathrm{mg} / 24 \mathrm{hr}$ ) (3.47 to $24.29 \mu \mathrm{mol} / 24 \mathrm{hr}$ ); 17-oxogenic-steroids $2.8 \mathrm{mg} / 24 \mathrm{hr}(9.71 \mu \mathrm{mol} / 24 \mathrm{hr}$ ) (normal: 3 to $8 \mathrm{mg} / 24$ hr) $(10 \cdot 41-27.76 \mu \mathrm{mol} / 24 \mathrm{hr})$; blood cortisol $15 \mathrm{mg} /$ $100 \mathrm{ml}(414 \mu \mathrm{mol} / \mathrm{l})$ (normal: 6 to $26 \mathrm{mg} / 100 \mathrm{ml}$ ); (165.6 to $717.6 \mu \mathrm{mol} / \mathrm{l})$; thyroid, liver, and renal function tests and blood chemistry were normal. A skull $x$-ray film showed a normal sella turcica.

Chromosome studies were carried out because of the findings on physical examination. Chromosome analysis from cultured peripheral blood lymphocytes showed a 46,XY normal male karyotype and buccal smears indicated a single normally sized fluorescent $Y$ body, thus confirming the diagnosis of testicular feminisation syndrome.

A vagotomy and pyloroplasty were performed to treat the peptic ulcer disease. Exploration of the pelvic region confirmed the absence of uterus, and in the Douglas pouch two gonads were found, attached to a ligamentous structure. These were removed.

\section{PATHOLOGICAL EXAMINATION}

Two elongated structures were submitted for pathological examination, each measuring $6.5 \times 1.0 \times 1.0$ $\mathrm{cm}$. The external surface was smooth and glistening. The cut surface was torn, elastic, and lobulated. The tissue was fixed in $10 \%$ buffered formalin.

On microscopical examination (Fig. 1-4) the haematoxylin-eosin stained slides showed numerous clusters of large Leydig cells with rare Reinke crystalloids. There were also scattered luteinised interstitial cells. In some areas, ovarian type cortical stroma was 


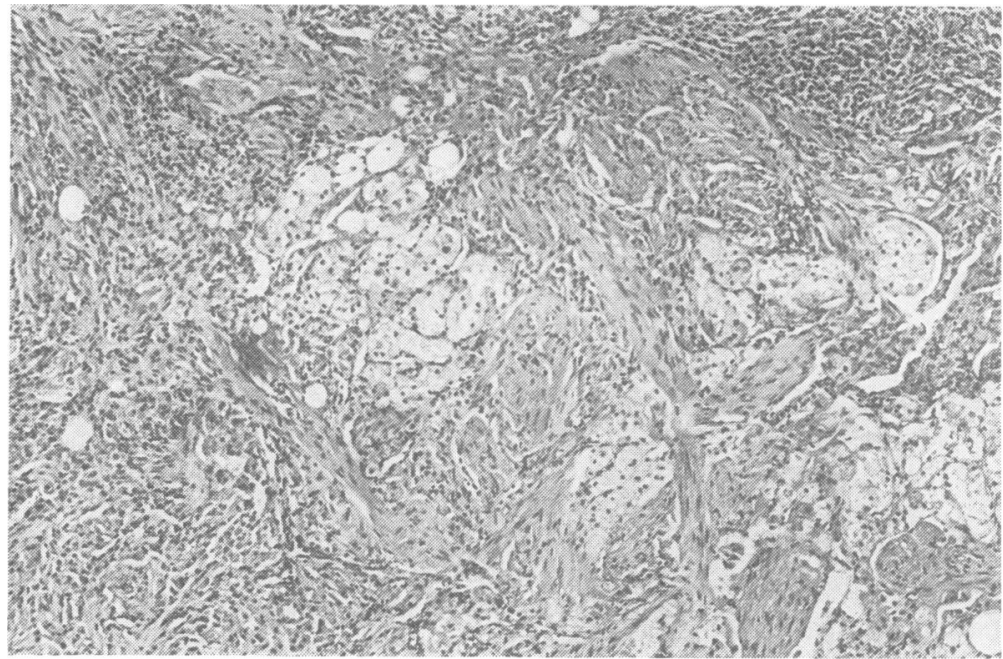

identified. The remaining stroma contained fibrous connective tissue, blood vessels, and numerous spindle cell muscular elements. The latter were arranged in interlacing bundles which reacted as smooth muscle when stained with Masson Trichrome and Van Gieson stains. No tubular structures were seen in numerous sections. Elastic tissue stained slides also failed to reveal remnants of such structures.

\section{Discussion}

The diagnosis of testicular feminisation syndrome is usually established in young adult women who fail to menstruate, and in young girls with inguinal hernias in which gonads can be palpated. The diagnosis of this disease in elderly women as in the present case $\mathrm{i}$. unusual. This may be because affected patients are conscious of their unusual phenotype and therefor $\hat{0}^{\circ}$ seek medical advice much earlier. In a series of $82 \mathrm{~N}$ patients collected from the literature by Morrio (1953), only 4 were over 60 years old and among the patients described by Weisberg et al. (1963), 2 wers diagnosed at 70 and 72 years, respectively. While the histological appearance of the gonads resembling cryptorchid testes in patients with this syndrome has been well described (Morris, 1953; Morris and Scully응 1958; Morris and Mahesh, 1963; Rainer, 1970 Stenchever et al. 1969; Weisberg et al., 1963), the

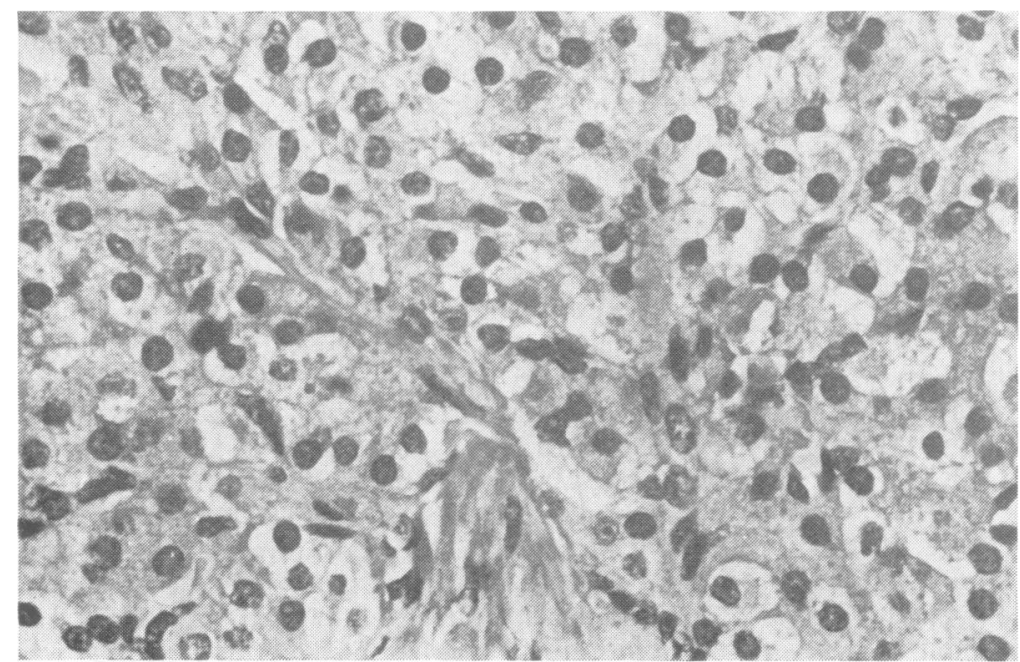

Fig. 2 Detail of prominent Leydig cells seen throughout the gonad. (Haematoxylin and eosin. $\times$ 336.) 


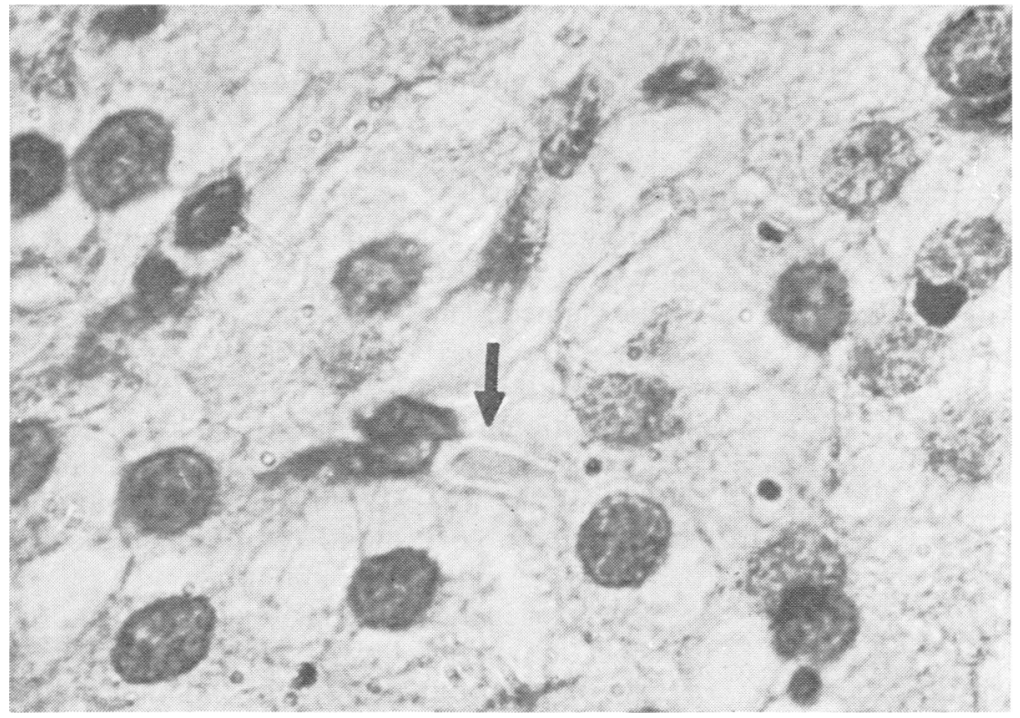

possible effect of advanced age on the histological features has not received special attention.

The unusual picture of the gonads in our case, with total absence of tubular structures or remnants thereof, can possibly be explained on the basis of fibrous replacement of these structures. The rare Reinke crystalloids within some of the Leydig cells appear to be the only evidence of the androgenic origin of these gonads.

The striking prominence of smooth muscular fibres seems to be more difficult to explain. It may have been of hamartomatous nature. Fibrous pro- liferation alone has been reported by Morris (1953). The other unusual feature of the gonads in this case, namely the presence of ovarian type stroma, has been previously described (Morris, 1953; Morris and Scully, 1958; Morris and Mahesh, 1963).

This report represents, to the best of our knowledge, the only detailed histological description of the gonads in a patient of advanced age with testicular feminisation syndrome. Because of the unusual microscopical appearance of the testes in old individuals with this syndrome, the microscopical appearance is of little help in establishing the correct

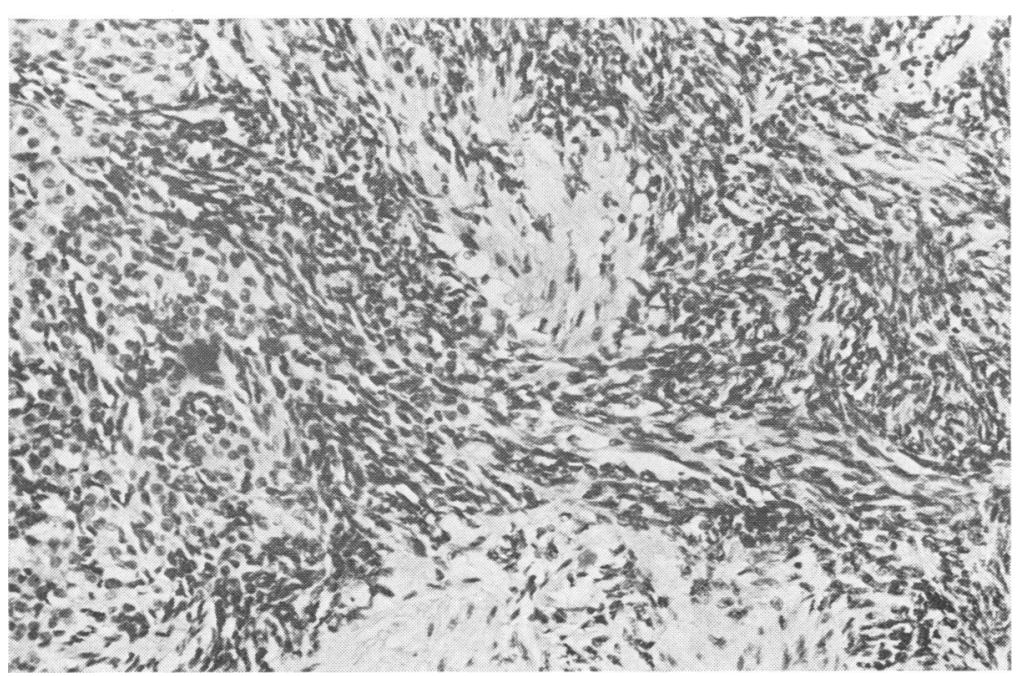

Fig. 4 Area in gonad with characteristic ovarian type stroma. (Haematoxylin and eosin. $\times 210$.) 
diagnosis, which in such cases should be based mainly on clinical and cytogenetic findings.

\section{J. Chemke, A. Shani, M. Lancet, And}

B. CZERNOBILSKY

The Clinical Genetics Unit, Department of Medicine ' $C$ ', Department of Obstetrics and Gynecology, and Department of Pathology, Kaplan Hospital, Rehovot, Israel.

\section{References}

Federman, D. D. (1967). Abnormal Sexual Development. W. B. Saunders, Philadelphia and London.

Morris, J. M. (1953). The syndrome of testicular feminization in male pseudohermaphrodites. American Journal of Obstetrics and Gynecology, 65, 1192-1211.

Morris, J. M., and Mahesh, V. B. (1963). Further observations on the syndrome 'testicular feminization'. American Journal of Obstetrics and Gynecology, 87, 731-748.

Morris, J. M., and Scully, R. E. (1958). Endocrine Pathology of the Ovary. C. V. Mosby, St. Louis.

O'Connell, M. J., Ramsey, H. E., Whang-Peng, J., and Wiernik, P. H. (1973). Testicular feminization in three sibs: emphasis on gonadal neoplasia. American Journal of the Medical Sciences, 265, 321-333.

Rainer, S. (1970). Histological picture of the gonads in testicular feminization. Acta Europea of Fertility, 2, 93-99.

Stenchever, M. A., Ng, A. B. P., Jones, G. K., and Jarvis, J. A. (1969). Testicular feminization syndrome: chromosomal, histologic, and genetic studies in a large kindred. Obstetrics and Gynecology, 33, 649-657.

Weisberg, M. G., Malkasian, G. D., Jr., and Pratt, J. H. (1963). Testicular feminization syndrome: a review and report of 6 cases. American Journal of Obstetrics and Gynecology, 87, 731-748.

Requests for reprints to Dr Juan Chemke, Clinical Genetics Unit, Kaplan Hospital, Rehovot P.O.B. 1, Israel.

\section{Mosaicism presumably related to a $\mathrm{Y} / 6$ translocation in a boy with multiple congenital abnormalities ${ }^{1}$}

SUMMARY A $3 \frac{1}{2}$-year-old boy was referred for chromosomal evaluation because of mental and developmental retardation, peculiar facies, and abnormalities of the extremities.

Karyotype analysis disclosed the presence of 46 and 47 chromosome cell lines. The 46 chromo-

1This research was supported in part by The National FoundationMarch of Dimes Grant No. 1-298 some line contained 4 normal G group chromosomes and an abnormally small $\mathrm{Y}$ identified by: $\mathrm{G}$ banding. Further investigation with $\mathrm{Q}$ and $\mathrm{C} \overline{\overline{\bar{s}}}$ band techniques revealed that the missing segmento of the $\mathrm{Y}$, the distal long arm, had been translo-음 cated to the end of the long arm of a number $\frac{\bar{\sigma}}{\sqrt{6}}$ 6 chromosome. This de novo rearrangement $\stackrel{\square}{\varrho}$ appeared to be balanced and was found in allø cells examined. The 47 chromosome line, which $\vec{\circ}$ had a frequency of $10 \%$ in the patient's leucocytes, was identical to the 46 line except for the presencee of an additional copy of the small chromosome. The morphology and banding patterns of theo two small acrocentrics in the aneuploid line $\overrightarrow{\vec{A}}$ were found to correspond to those of the deris (derivative) $\mathrm{Y}$ in the euploid line.

The cytogenetic findings suggest that theo translocation was followed by non-disjunction? of one of its products resulting in mosaicism. Possible causes for the clinical and karyotypic abnormalities are discussed.

Fluorescent banding has greatly facilitated the study $\vec{\theta}$ of structural changes involving the $Y$ chromosome.. Translocation of the distal segment of Yq is easily determined by this technique, and a number of such exchanges have been reported. Some of these translocations (Noel et al., 1971; Friedrich and Nielsen, 1972; Frund et al., 1972) have had no apparent ${ }^{\circ}$ phenotypic effects on the individuals carrying them. In other cases (Develing et al., 1973; Gilgenkrantz을 et al., 1973; Pfeiffer et al., 1973). Y autosomal exchanges have occurred in association with deleterious phenotypic abnormalities. We wish to report a case of a de novo translocation in which the entire distal fluorescent segment of the $Y$ has become attached to the tip of $6 \mathrm{q}$. Though no loss of chromosomal 3 . material is detectable, the propositus is moderately retarded and has multiple congenital abnormalities. 3 His cytological picture is complicated by the presence of an aneuploid cell line containing the translocation and what appears to be two copies of the derivative 0 (der) Y. This cell line occurs with a frequency of $10 \%$ in the patient's leucocytes.

\section{Case report}

The propositus is a $3 \frac{1}{2}$-year-old caucasian boy with ${ }^{2}$ developmental and mental retardation, peculiar? facies, and abnormalities of the extremities. The mother was 42 and the father 51 at the time of birth.+ The mother, who was unaware of the pregnancy, underwent cholecystectomy preceded by a series of $X$-rays about the time of conception. She had also $\frac{}{\mathrm{d}}$ 